\title{
Intra-industry Trade Exposure, Fragmentation, and Labor Adjustment
}

\author{
Barbara Dluhosch \\ Helmut Schmidt University - University FAF Hamburg
}

\begin{abstract}
Over the last two decades, labor market prospects of the low skilled in OECDcountries deteriorated sharply. Developments like these have been frequently traced back to low-cost competition from abroad. Yet, the Heckscher-Ohlin hypothesis is hard to reconcile with the fact that OECD-trade is for the most (and growing) part intraindustry trade (IIT). IIT is usually regarded as much less disruptive as it is considered to affect the regional composition of product demand, but not necessarily labor demand. The paper proposes a model of trade-induced technology choice in which, contrary to many beliefs, IIT generates substantial shifts in labor demand and employment. These changes are due to technology implementation being associated with spill-over effects related to business services and production fragmentation within and across firms. The model can account for a number of stylized facts of OECD-labor markets, including the bimodal growth of high and low-skilled services employment, and the recent concentration of demand for skill in management and business-service occupations, and is in line with statistics based on input-output tables suggesting that production methods changed in tandem with exposure to foreign competition.
\end{abstract}

- JEL classification: F16, J23, J31, O33

- Keywords: Intraindustry trade, Technology choice, Labor demand, Occupational change, Job and worker flows

\footnotetext{
*Corresponding address: Helmut Schmidt University - University FAF Hamburg, Department of Economics, Holstenhofweg 85, 22043 Hamburg, Germany, E-mail: dluhosch@unibw-hamburg.de. (C2006-Center for International Economics, Sejong Institution, All Rights Reserved.
} 


\section{Introduction}

For the last two decades OECD-labor markets have been characterized by considerable disruptions. Some countries experienced a rising gap in compensation between skill groups; others suffered from high and rising unemployment. This experience initiated a debate among researchers as to whether these changes can be traced back to trade or technology. Though some studies do find considerable trade-induced labor effects, ${ }^{1}$ it turned out to be hard to find evidence in support of the trade hypothesis. ${ }^{2}$

This is because a number of empirical observations are inconsistent with the hypothesis that low skilled competition from abroad (i.e. North-South trade) either forced down wages for the low skilled in OECD-countries or led to their unemployment: (i) firms increased their demand for high skilled labor, despite the rise in the skill premium while according to North-South trade theories based on factor proportions we should observe the exact opposite, namely that skill intensity of production decreases across all industries; ( $i$ i) OECD-trade is largely intraindustry trade (IIT), that is North-North trade, and not interindustry trade along Heckscher-Ohlin lines: in the U.S., the share of manufacturing IIT in total manufacturing trade increased from 63.5 (1988-91) to 68.5 (1996-2000), for Germany numbers are 67.1 and 72.0 respectively, and in the U.K. IIT rose from 70.1 to 73.7 percent. In some of the Eastern European Countries IIT outpaced HOtrade even stronger: in Poland it increased from 56.4 to 62.6, in Hungary from 54.9 to 72.1; and the Czech Republic witnessed an increase from 66.3 to 77.4 within an even shorter time span (from 1992-1995 to 1996-2000) (OECD 2002a). IIT, however, is generally regarded as much less disruptive with respect to labor markets as it is considered to affect the regional composition of product demand, but not necessarily labor demand (Balassa (1966)). Though there have been some doubts raised in the literature as to the general validity of this presumption (e.g.

\footnotetext{
${ }^{1}$ E.g. Hijzen/Görg/Hine (2005); According to pioneering work by Davis/Haltiwanger/ Schuh (1996) in this field data on U.S. job creation and destruction does not suggest that job turnover and trade are correlated. However, their results were largely due to the fact that they compared 14-year averages of trade exposure and job flows in five categories of industries (classified according to import penetration ratios and share of output devoted to exports) at the 4-digit SIC level. Year-to-year movements in trade exposure and labor flows yield a much richer picture of the links between trade and labor flows (Klein/ Schuh/Triest (2003)). On the empirical relationship between import penetration (defined as the ratio of imports to new supply), competition and employment (risk) see also Clark/Herzog/Schlottmann (1998).
}

${ }^{2}$ See Gaston/Nelson (1997) for an overview. 
Finger (1975), Lovely/Nelson (2002), Greenaway/Haynes/Milner (2002), Brülhart/ Murphy/Strobl (2004)), findings have not been linked to the many dimensions in which labor markets have changed recently. ${ }^{3}$

A more detailed examination of labor statistics reveals that the increase in the skill premium was accompanied by substantial shifts in the structure of employment (OECD 2001) which have gone largely unnoticed in trade explanations. In particular, employment in service activities rose in tandem with the exposure of local to foreign competition. ${ }^{4}$ The increase in services employment was by no means limited to low-skilled, poorly paid jobs, but rather has exhibited a bimodal pattern with growth especially strong at the lower and the upper end of the wage scale. In addition, employment of professional, management and salesrelated personnel has increased substantially faster than in other high skilled groups. ${ }^{5}$ These developments are indicative of fundamental changes in production methods and technology at the same time as economies increasingly open up, in particular since there is evidence that worker reallocation occurred to a substantial extent not only between sectors, but also at the firm or industry level (see Davis/ Haltiwanger/Schuh (1996), Haltiwanger/Schuh (1999) and Bauer/Bender (2004) for empirical evidence on this phenomenon).

This paper proposes a model in which IIT generates changes in employment between sectors, industries and occupations similar to the pattern labor statistics

\footnotetext{
${ }^{3}$ An alternative explanation draws on shifts in either demand or technology. According to Berman/Bound/ Machin (1998) changes in technology implied shifts in the composition of the workforce, in particular an upskilling of the labor force at the level of the firm and an increase of non-production workers at the expense of production workers. However, a pure technology explanation like this is hard to reconcile with the fact of economies increasingly open up as in the latter situation labor demand is affected to the extent that technical change is biased with respect to sectors, but not with respect to factors of production.
}

${ }^{4}$ In the US, manufacturing's share of employment fell from $22.1 \%$ in 1980 to $18.0 \%$ in 1990 to $14.0 \%$ in 2001 , in the U.K. from $25.2 \%$ in 1980 to $18.0 \%$ in 1990 to $13.5 \%$ in 2002 , in Germany from $33.9 \%$ in 1980 to $31.6 \%$ in 1990 to $24.1 \%$ in 2000 .

${ }^{5}$ In the period March 1995 to March 2001, 31\% of net US employment growth occurred in occupational categories "administrative and managerial"; $39.4 \%$ came in the category "professional, technical and related". During the same period, the groups "production and related, transport equipment, operators and laborers" accounted for only $9.2 \%$ of new net job growth. In Germany, the two groups "professionals and managers" were responsible for $73 \%$ of total employment growth while employment of "craft workers, plant and machine operators" declined. In the U.K., shifts were somewhat less pronounced, but still observable. On changes in employment by industry see ILO Bureau of Statistics (2003) (Table 2B), OECD (2001) and U.K. Office for National Statistics (2003) (Workforce Jobs by Industry) for the US, Germany and the U.K. respectively. Employment by occupation has been taken from the ILO Bureau of Statistics (Table 2C). 
show for the last two decades. In the model, changes in employment are due to shifts in labor demand as economies open up: the size of the market affects technology choice, in particular with respect to the extent of fragmentation, which in turn affects labor demand in several dimensions. This transmission mechanism from IIT to labor via technology draws on empirical evidence based on InputOutput tables (e.g. Campa/Goldberg (1997); Baldone/Sdogati/Tajoli (2001); Hummels/Ishii/Yi (2001), Yi (2003)) which suggest that in the last twenty years or so value added tended to grow much slower than production. The fact that value added grew much slower indicates that firms increasingly relied on (imported) intermediates, either in the way of arms-length production or via intrafirm trade (on evidence for the latter see OECD (2002a, 2003), Rangan (2001), and Zeile (1997)). However, according to firm panel data, similar developments took place within firms; changes in the organization of production and occupations suggest that the vertical division of labor (i.e. production fragmentation) within firms increased as well (Bauer/Bender (2004)).

The focus on fragmentation is all the more warranted as there is evidence that the cost effectiveness of fragmentation increases as markets open up. The productivity effect is related to business services necessary in production fragmentation, in particular to business software applications. The latter are crucial for managing a fragmented production process, and thus for the cost effectiveness of fragmentation. Economically, business software has two outstanding features: the market structure of the business services industry as well as the nature of business software development and implementation suggest that the effectiveness in cost reduction is larger the more firms make use of new technology. The improvement in productivity, in turn, is due to two effects, namely the importance of external sources (in particular customers) in the business software development process (Segelod/Jordan (2004)), and the fact that the supply side of the corporate software industry is fairly concentrated. One firm serves many customers, ${ }^{6}$ making knowledge spillovers with respect to customers and the productivity of the software likely. Hence, due to multifirm experience software is more to the problem, i.e. productivity increases with the number of firms served.

Accordingly, in the framework presented in this paper, trade-induced changes in

\footnotetext{
${ }^{6}$ Based on worldwide license revenues for business software applications, the largest firm, SAP, had, according to financial analysts and company data (SAP (2003)), an estimated market share of 54\% (Q2 2002-Q1 2003), followed by Oracle (14\%), Siebel (13\%), PeopleSoft (11\%), JD Edwards (5\%) and I2 $(3 \%)$.
} 
the skill composition of labor demand and the reallocation of labor between sectors, industries and occupations originate from two sources: $(i)$ due to learning and experimentation, cost effectiveness of fragmentation is larger the more firms make use of new technology. Therefore, fragmentation changes endogenously with respect to trade integration and so does the composition of labor demand with respect to skills and occupations; ( $i$ i) costs of coordinating and supervising a fragmented production process change endogenously as barriers to trade are removed. Via these channels, trade-induced fragmentation has important implications for labor adjustment. In fact, the model is able to generate endogenous job and worker flows which match the stylized facts, including the bimodal growth of high and low skilled services employment observed in OECD countries, as well as the recent concentration of demand for skill in management and business services occupations. In an increasingly fragmented production process firms increase their demand for management skills - at the expense of unskilled employment in direct production. Total firm-level employment may well increase (or remain unaffected) though, despite job destruction and workers being laid off. By endogenizing technology and tracking job destruction and creation induced thereby the paper challenges the common view that adjustment costs of IIT are (generally) low (as far as the adjustment takes place within firms and thus goes unreported, the effect of IIT may even be underestimated) and in doing so, it tries to reconcile labor market developments with trade explanations, in particular with the growing share of IIT.

The paper is organized as follows. Section 2 offers a brief review of how the paper relates to the literature. Section 3 sets out the basic model of IIT and endogenous production technique, and illustrates the central role of business services related spillovers. Section 4 presents consequences of induced technical change along these lines for labor adjustment when opening up. Finally, Section 5 discusses results in light of empirical findings.

\section{Contribution to the Literature}

In order to acknowledge the fact that OECD-trade is for the most part (and with the fraction increasing) IIT and to capture labor flows within industries, ${ }^{7}$ we employ a North-North perspective using an IIT framework rather than a NorthSouth perspective for which an interindustry-trade framework may be appropriate. In so far, the perspective is related to the literature on IIT and labor adjustment, as, 
for instance, Lovely/Nelson $(2000,2002)$. However, while these contributions discuss the general validity of the commonly held view than IIT involves relatively less labor reallocation compared to other trade, we take up recent labor market developments. In particular, we include the bimodal growth of high- and lowskilled services employment and the shift towards management, that is the change in occupations, and we also address the vertical dimension of the firm as the data suggests a link between both.

As far as the fragmentation of production, i.e. the vertical issue, is concerned, it shares aspects of Jones/Kierzkowski (1990), Feenstra/Markusen (1994), Deardorff (2000), and Feenstra/Hanson (2003) who also examine the nexus of trade and production modes. In their framework, fragmentation is largely driven by factor proportions and factor intensity of intermediates production though. In order to focus as sharply as possible on purely IIT-induced technology and labor adjustment, we will abstract from these issues and instead concentrate on a quite different mechanism triggering a change in production modes which, as we will show shortly, is also accompanied by substantial shifts in labor demand. In doing so, we stay more closely with the literature on the question whether (pure) IIT may involve considerable labor market disruptions (and without re-introducing factor proportions trade through the backdoor).

By drawing on technical change related to fragmentation on the one hand and on the economic characteristics of business services on the other hand we address the recent concentration of demand for skill in management and business-services occupations which are a remarkable fact of labor market statistics as well as employer-employee panel sets. Therefore, our approach also differs from the previous literature on trade-induced technical change. ${ }^{8}$ In Ekholm/Midelfart Knarvik (2005), cost functions are postulated and thus exogenously introduced rather than derived endogenously. In Thoenig/Verdier (2003) technological change

\footnotetext{
${ }^{7}$ On the reverse link from labor flows to trade see Davidson/Matusz (2005) and Magee/Davidson/Matusz (2005) who find that trade patterns across industries are correlated with worker turnover in the sense that different rates of turnover, both, across industries and countries, give rise to comparative advantage. By increasing labor unit costs they affect net exports of industries. Yet, since the authors adopt an interindustry perspective, they are unable to account for the part of job turnover that recently took place within OECD-industries (in particular the shift in employment among occupations and the upskilling of the workforce).

${ }^{8}$ Andersen/Sørensen (2005), though discussing the possibility of trade induced technical change, do not refer to the vertical dimension nor to the changes in occupations which took place; Falvey/Reed (2000) expect a shift towards more unskilled labor intensive techniques in developed countries due to tradeinduced technical change - which differs from actual developments.
} 
is triggered by firms trying to defend market share in a framework of imitation and innovation with the focus on consequences for the skill-dimension of labor demand only; similar to Neary (2002a,b), who focuses on R\&D-specialization of firms threatened by import competition, however, in contrast to Thoenig/Verdier, in an oligopolistic framework.

With Francois (1990), Jones/Kierzkowski (1990) and Francois/Nelson (2000) our model stresses the role of services and skills in a fragmented production process. However, these authors employ a framework much different from our setup, and without reference to recent job and worker flows or spillovers with respect to the cost effectiveness of fragmentation related to business services. With respect to fragmentation and the crucial role of business services we build on previous work by Burda/Dluhosch (2002). To account for IIT, we first apply the microfoundations of fragmentation, as developed in their paper, to the Krugman (1980) intra-industry trade model. ${ }^{9}$ Second, we develop the model insofar one step further as we explicitly focus on the economic characteristics of business services which may involve spillover effects, and consider the labor flows induced thereby. ${ }^{10}$ Thus far, both of these approaches were unable to account for simultaneous job creation and destruction of firms due to trade-induced changes in technology. The latter considers technology as invariant to integration, while the former treat technology as endogenous, but do not consider trade nor spillover effects from implementing new fragmentation technologies.

\section{The Model}

Let there be two groups of final goods for consumption which enter utility of a representative consumer according to a Cobb-Douglas function with expenditure shares $(1-\mu)$ and $\mu$ respectively, namely $(i)$ homogenous consumer services $x_{0}$ and (ii) differentiated manufactures $x_{i}$ (with $i=1, \ldots, n$ ) along the lines of Dixit/Stiglitz (1977).

\footnotetext{
${ }^{9}$ In applying the microfoundations of fragmentation to the Krugman setup, it also differs from most contributions to the theory of fragmentation which primarily focus on the international allocation of intermediates production governed by the love-of-variety mechanism. On this see for instance, Ethier (1982), Venables (1999).

${ }^{10}$ In Burda/Dluhosch (2002) employment ratios remain unaffected (despite the rise in the skill premium) unless cost effectiveness of fragmentation changes endogenously, a possibility which they did not consider.
} 


$$
U=x_{0}^{1-\mu}\left(\sum_{i=1}^{n} x_{i}^{\frac{\eta-1}{\eta}}\right)^{\frac{\eta \mu}{\eta-1}}
$$

This set up is in line with the majority of the intra-industry trade literature and acknowledges the fact that most of the OECD trade is IIT with the share in total trade increasing. For given income $Y$, utility maximization for the representative household gives rise to the familiar demand functions (with consumer services serving as numéraire)

$$
\begin{gathered}
x_{i}=\left(\sum_{j=1}^{n} p_{j}^{1-\eta}\right)^{-1} \mu Y p_{i}^{-\eta} \\
x_{0}=(1-\mu) Y
\end{gathered}
$$

so that for $n$ large, the elasticity of demand for manufactures is approximately $\eta$.

\section{A. Product Markets: Supply and Demand}

In order to account for the vertical dimension direct production of each of the differentiated goods is considered an intermediate sector within manufacturing. Production in this sector takes place by use of high- and low-skilled labor, $H_{P}$ and $L_{B}$ according to a constant returns production function $f\left(H_{P}, L_{P}\right)=H_{P}^{\theta} L_{P}^{1-\theta}$. The associated costs are modeled to represent payments for the output of a perfectly competitive intermediate sector sold at price $p_{c}{ }^{11}$

Though for given technology production is constant returns, the specific technology used depends on market size. In order to realize economies of scale as markets expand, production processes in manufacturing may be fragmented into an (endogenous) number $(z)$ of production steps. This production fragmentation is associated with variable cost savings according to the following function $v(z)=$ $\bar{v} z^{-\psi}$, with $\psi$ denoting the effectiveness of fragmentation in cost reduction. Ceteris paribus, a finer division of labor in manufacturing thus yields lower costs. Net cost savings, however, depend on $(i)$ the number of firms that make use of these cost saving technologies and on (ii) the costs associated with implementing and employing a more fragmented production.

\footnotetext{
${ }^{11}$ This makes the cost function consistent with a primal problem in two factors of production. One way of thinking about this is to regard the input as being supplied by a perfectly competitive manpower industry to the manufacturing sector in the form of a composite of the two labor types at minimum cost conditions, given factor prices. Yet, fragmentation of production processes in manufacturing allows to reap economies of scale (see next paragraph).
} 
Ad (i): the number of firms in the market (and therefore market size) matters if technologies are more adapted to specific tasks the larger the group of producers who make use of these technologies. The reason for this may be some indivisibility associated with the technology which in turn may be due either to spill-over effects in the sense that there is more learning and more experience the larger the number of users for any given technology so that solutions are more tailored to problems or in the sense that it pays to develop technologies which were not sustainable before (at smaller market size). In both of these cases cost savings increase with market size, competition - and trade exposure. For reasons of tractability we will assume that the effectiveness of fragmentation in cost reduction increases with the number of firms $n$ according the following specific function $\psi=\alpha \ln (n+1)$. Below we will impose restrictions on parameter $\alpha$ so that fragmentation is not too effective in cost reduction to make sure that the model yields economically feasible results. On the one hand production fragmentation thus yields benefits in the sense that it lowers marginal production costs.

Ad (ii): on the other hand, the more fragmented production technique implies more effort in terms of coordinating, supervising and designing production processes. The latter activities require the input of high skilled business services (which compete for high-skilled labor with direct production). We will assume that these business services can be bought at market price $p_{Z}$, so that the trade off between these two cost components is a matter of relative prices. Relative prices in turn will be determined inter alia by labor markets, an issue to be dealt with more explicitly in subsection B.

If production is subject to fixed $(\bar{F})$ and variable costs $(v(z))$ as well as costs for business services $\left(p_{Z}\right)$, total production costs for firm $i$ are given by

$$
\bar{F}+\bar{v} z_{i}^{\mu /} x_{i}+p z^{z_{i}}
$$

Costs in direct production $\bar{F}+\bar{v} z_{i}^{-\psi} / x_{i}$ for $n$ firms thus equal costs of the composite of the two labor types at minimum cost conditions $p_{c} f\left(H_{B}, L_{P}\right)$, supplied by the intermediate manpower industry. Ignoring the integer problem, the equality holds for a sequence of production modes, each for given output, number of firms and extent of fragmentation. Profits $\pi_{i}$ of the representative firm in manufacturing are

$$
\pi_{i}=p_{i} x_{i}-\left(\bar{F}+\bar{v} z_{i}^{-\psi} x_{i}+p_{Z_{i}}\right)
$$


Optimal behavior of firms in symmetric product market equilibrium (with $p_{i}=p$; $\left.x_{i}=x, z_{i}=z ; \forall i=1, \ldots, n\right)$ then yields scale (6), price (7), and extent of fragmentation (8) of each firm in the differentiated goods sector in partial equilibrium (given low skilled services employment $L_{s}$ and price of business services $p_{Z}$ ).

$$
\begin{gathered}
x=\frac{\bar{F}(\eta-1)}{(1-(\eta-1) \alpha \ln (n+1)) \bar{v}}\left(\frac{\bar{F}(\eta-1) \alpha \ln (n+1)}{p_{Z}(1-(\eta-1) \alpha \ln (n+1))}\right)^{\alpha \ln (n+1)} \\
p=\frac{\eta}{(\eta-1)}\left(\frac{(1-(\eta-1) \alpha \ln (n+1)) p_{Z}}{\bar{F}(\eta-1) \alpha \ln (n+1)}\right)^{\alpha \ln (n+1)} \bar{v} \\
z=\frac{\bar{F}(\eta-1) \alpha \ln (n+1)}{(1-(\eta-1) \alpha \ln (n+1)) p_{Z}}
\end{gathered}
$$

To limit attention to economically meaningful equilibria, it is assumed that $\alpha$ is small enough: $\alpha<1 /((\eta-1) \ln (n+1))$.

Free entry implies that profits are driven to zero. The zero profit condition provides information about the relationship between the number of firms $n$ and low skilled services employment $L_{S}(9){ }^{12}$

$$
n=\left(\frac{\mu}{1-\mu}\right) \frac{L_{S}(1-(\eta-1) \alpha \ln (n+1))}{\eta \bar{F}}
$$

Before modeling labor markets and closing the model we have to take a look at business services and consumer services production.

If firms fragment production, economy-wide demand for business services is given by $n z=Z$. These business services are supplied at price $p_{Z}$ by competitive, profit maximizing firms which use skilled labor $H_{S}$ according to the constant returns technology $Z=H_{S}$, so that the derived demand for labor in business services is infinitely elastic at $p_{Z}$, which, in a competitive labor market, will equal the equilibrium wage. The market price for business services $p_{Z}$ also equates demand for business services $z$ from $n$ manufacturing firms with total supply:

\footnotetext{
${ }^{12}$ Equation (9) may be solved for $n$ :

$n=\frac{\mu}{(1-\mu)} \frac{(\eta-1)}{\eta} \frac{\alpha L_{S} \operatorname{ProductLog}\left(\frac{\eta}{(\eta-1)} \frac{(1-\mu)}{\mu} \frac{\bar{F}}{\alpha L_{S}} e^{\frac{\mu L_{S}+\eta \bar{F}(1-\mu)}{\mu(\eta-1) \alpha L_{S}}}\right)}{\bar{F}}-1$.
}

However, it is more convenient to work with (9). 


$$
\frac{\mu}{(1-\mu)} \frac{(\eta-1)}{\eta} \frac{\alpha \ln (n+1)}{p_{Z}} L_{S}=H_{S}
$$

Finally, consumer services are supplied under conditions of perfect competition, employing unskilled labor and using the technology

$$
x_{0}=L_{S}
$$

Since consumer services serve as numéraire, labor demand originating in this sector is infinitely elastic at unity, the value marginal product of unskilled labor in these services. To summarize: manufactures are produced by use of high and low skilled labor, consumer services by low skilled labor only. Production of manufactures, however, requires the input of high-skilled business services to coordinate fragmented production processes.

With labor demand derived from product market conditions we are able to describe labor markets in more detail and determine prices in general equilibrium before opening up to trade and considering trade-induced job and worker flows.

\section{B. Labor Markets: Supply and Demand}

Let the economy be populated with high and low skilled labor in proportion $\kappa=L / H$, with each type of labor supplied inelastically by households in the two forms, skilled $H$ and unskilled $L$, to perfectly competitive labor markets. Since the focus of the paper is on the effects of market size proper (i.e. pure IIT) and to keep the model as simple as possible we will abstract from any factor proportions driven specialization effects and assume that both skills are supplied in proportion $\kappa=1$. In addition, we will assume that mobility between sectors is costless, so that the demand curve for each type of labor in each sector is the "supply price" to the other. Due to worker and job heterogeneity with respect to skills and occupations, this model-economy generates labor flows in addition to net sectoral employment changes which resemble recent developments.

With these assumptions, the relevant labor market equilibrium conditions are the equality of wage and value marginal product in direct production and services (business and consumer) for both types of labor

$$
\begin{gathered}
1=p_{c}(1-\theta)\left(\frac{H-H_{S}}{L-L_{S}}\right)^{\theta} \\
p_{Z}=p_{c} \theta\left(\frac{L-L_{S}}{H-H_{S}}\right)^{1-\theta}
\end{gathered}
$$


Since $p_{Z}$ is endogenous, it will be influenced by conditions prevailing in labor markets, which in turn affect the extent of fragmentation $(z)$. The model is closed using the market clearing condition that the value of demand for the direct cost input in manufacturing from $n$ firms equals supply:

$$
\frac{\mu}{(1-\mu)} \frac{(\eta-(\eta-1) \alpha \ln (n+1))}{\eta} L_{S}=p_{c}\left(H-H_{S}\right)^{\theta}\left(L-L_{S}\right)^{1-\theta}
$$

\section{The Allocation of Labor Pre-integration in Trading Equilibrium}

The model thus consists of a system of ten equations ((3) and (6)-(14)) in ten unknowns $x_{0}, x, p, z, n, p_{Z}, p_{c}, Y, L_{S}$ and $H_{S}$. It can be reduced to the following three equations in three unknowns $L_{S}, H_{S}$ and $n$

$$
\begin{gathered}
H=\frac{n \bar{F}(\eta(1-\mu \theta)-\mu(1-\theta)(\eta-1) \alpha \ln (n+1))}{\mu(1-(\eta-1) \alpha \ln (n+1))} \\
\frac{H_{S}}{H-H_{S}}=\frac{\mu n \bar{F}(1-\theta)(\eta-1) \alpha \ln (n+1)}{\theta(\mu H(1-(\eta-1) \alpha \ln (n+1)-n(1-\mu) \eta \bar{F}))} \\
\frac{L_{S}}{L-L_{S}}=\frac{(1-\mu)}{\mu} \frac{\eta}{(1-\theta)(\eta-(\eta-1) \alpha \ln (n+1))}
\end{gathered}
$$

Equations (16) and (17) yield ratios of services to direct production employment of high- and low-skilled workers. The system may be further reduced to a system in two equations (17) and (18) by eliminating $H$ in (16):

$$
\frac{H_{S}}{H-H_{S}}=\frac{(\eta-1) \alpha \ln (n+1)}{\theta(\eta-(\eta-1) \alpha \ln (n+1))}
$$

Alternatively, we can take the inverse function of (15) and eliminate $n$ in (16) and (17) to obtain employment ratios as a function of the (exogenous) supply of labor $H$.

In order to examine the impact of trade on technology and labor flows we introduce a second country. Variables related to Foreign are denoted by an asterisk. Furthermore, we distinguish values of variables ex ante and ex post integration by using superscript ie when referring to the world economy. Factor endowments for the integrated economy (i.e. Home and Foreign taken together) are thus 
$H^{i e}=H+H^{*}$.

Due to the endogeneity of the cost effectiveness in fragmentation, fragmentation in this model is driven by the size of the economy (or the world economy in trading equilibrium), as are employment flows. The larger is the market, the larger is the number of users of new technology, and the higher is the effectiveness of fragmentation in cost reduction so that for any given relative price of business services firms adopt a more fragmented production technique. Consequently, they reduce skilled and unskilled employment in direct production while increasing their demand for skill in management and business services. ${ }^{13}$

What is the pattern of worker and job flows and net sectoral changes in employment that we can expect if economies open up to trade? We assume that FPE holds in trading equilibrium (i.e. $w_{H}^{T}=w_{H}^{* T}=w_{H}^{i e} ; w_{L}^{T}=w_{L}^{* T}=w_{L}^{i e}$, with the superscript $T$ denoting values in trading equilibrium) ${ }^{14}$ In addition, we will assume that trade only takes place with respect to final goods. One could also think of the

${ }^{13}$ Note that the first derivative of $(15)$ with respect to $n$ is positive within the economically feasible and relevant parameter range $0<\alpha<1 /(\eta-1) \ln (n+1)$ :

$$
\begin{aligned}
& \frac{\partial\left(\frac{n \bar{F}(\eta(1-\mu \theta)-\mu(1-\theta)(\eta-1) \alpha \ln (n+1))}{\mu(1-(\eta-1) \alpha \ln (n+1))}\right)}{\partial n}=\frac{\bar{F}}{\mu(n+1)(1-\alpha(\eta-1) \ln (n+1))^{2}} \\
& \times\left(\begin{array}{c}
\left.(n+1)(1-\alpha(\eta-1) \ln (n+1))\left(\begin{array}{c}
\eta(1-\mu \theta) \\
-\mu(1-\theta)((\eta-1) \ln (n+1))
\end{array}\right)\right)>0 \\
+n \alpha(\eta-1)(\eta(1-\mu \theta)-\mu(1-\theta))
\end{array}\right)
\end{aligned}
$$

As $\eta>\mu$ and $(1-\mu \theta)>(1-\theta)$ both terms in brackets are larger than zero. Hence, the derivative is positive. Therefore, the number of firms $n$ strictly increases with market size $H$. Yet, if $n$ increases with market size so does the share of services employment in total employment, both for low and high skilled labor

$\left(\frac{\partial\left(\frac{L_{S}}{L-L_{S}}\right)}{\partial n}=\eta \alpha \frac{(1-\mu)(\eta-1)}{\mu(1-\theta)(n+1)(\eta-\alpha(\eta-1) \ln (n+1))^{2}}\right)>0$

and

$\left(\frac{\partial\left(\frac{H_{S}}{H-H_{S}}\right)}{\partial n}=\alpha \frac{\alpha(\eta-1) \eta}{\theta(n+1)(\eta-\alpha(\eta-1)(\ln (n+1)))^{2}}\right)>0$

These results differ from traditional intra-industry models à la Krugman (1980) in which both the scale of operation as well as prices of manufactures neither depend on factor endowments nor on market size, but remain unchanged despite (trade-)integration. In those models, the extent of the market is only relevant for the equilibrium number of firms. 
possibility of specialization augmented fragmentation, with parts of direct production shifted to Foreign due to differences in factor intensities and endowments (as Feenstra/Hanson (2003) for instance do). However, there are two reasons for concentrating on the labor market effects of trade in final goods and intraindustry trade in particular. First, horizontal trade can to a large extent accommodate for international differences in factor proportions. When adding vertical trade, the pattern of production and labor flows thus depends on (arbitrary) assumptions about the division of trade into a vertical and a horizontal component. Second, the aim of the paper is to examine labor-flow consequences of market size and enlargement, that is, of IIT proper. Therefore, we abstract from differences in factor proportions and focus on the extent of fragmentation.

In order to examine labor market consequences of trade exposure (pure IIT) consider the benchmark case of two identical economies that open up to trade with $H=H^{*}$. Since both economies are identical in terms of size and factor proportions, Home's (as well as Foreign's) value of gross exports equals her value of gross imports in differentiated goods. With trade in fact only in differentiated goods, and thus of the IIT type, the equilibrium condition on the trade balance reduces to

$$
H n^{* T}=H^{*} n^{T}
$$

so that $n^{T}=n^{T *}$ for all values of $H=H^{*}$. Since cost effectiveness in fragmentation is driven by the total number of firms (in the world economy) adopting a technology, firms choose a more fragmented production technology when the trading area expands at any given relative price of management services. Therefore, the number of firms in the trading area rises less then in proportion with factor endowments. Figure 1 depicts the consequences of trade exposure for the number of firms and occupational employment ratios for high and low skilled labor in Home and Foreign with the following parameter values used in the calibration exercise

\begin{tabular}{|c|c|c|c|c|c|c|c|}
\hline Parameter & $\mu$ & $\theta$ & $\eta$ & $\alpha$ & $\bar{F}$ & $\kappa=\kappa^{*}=\kappa^{i e}$ & $H=H^{*}$ \\
\hline Value & 0.5 & 0.5 & 2 & 0.5 & 1 & 1 & 50 \\
\hline
\end{tabular}

Panel (a) depicts the inverse function of (15), i.e. the relationship between the number of firms and the size of the trading area as measured by factor supplies in

\footnotetext{
${ }^{14}$ As long as FPE holds, wages with trade are the same in Home and in Foreign as well as in the (fiction) of the integrated (world) economy. However, since with respect, for instance, to production it is important to differentiate between trade values of variables for Home and for Foreign and for the world economy we introduce both superscripts $i e$ and $T$ throughout the analysis.
} 
Figure 1. Impact of trade exposure on the number of firms (Panel (a))

Occupational employment ratios, i.e. services to production workers, high and low skilled (Panel(b), (Panel (c))

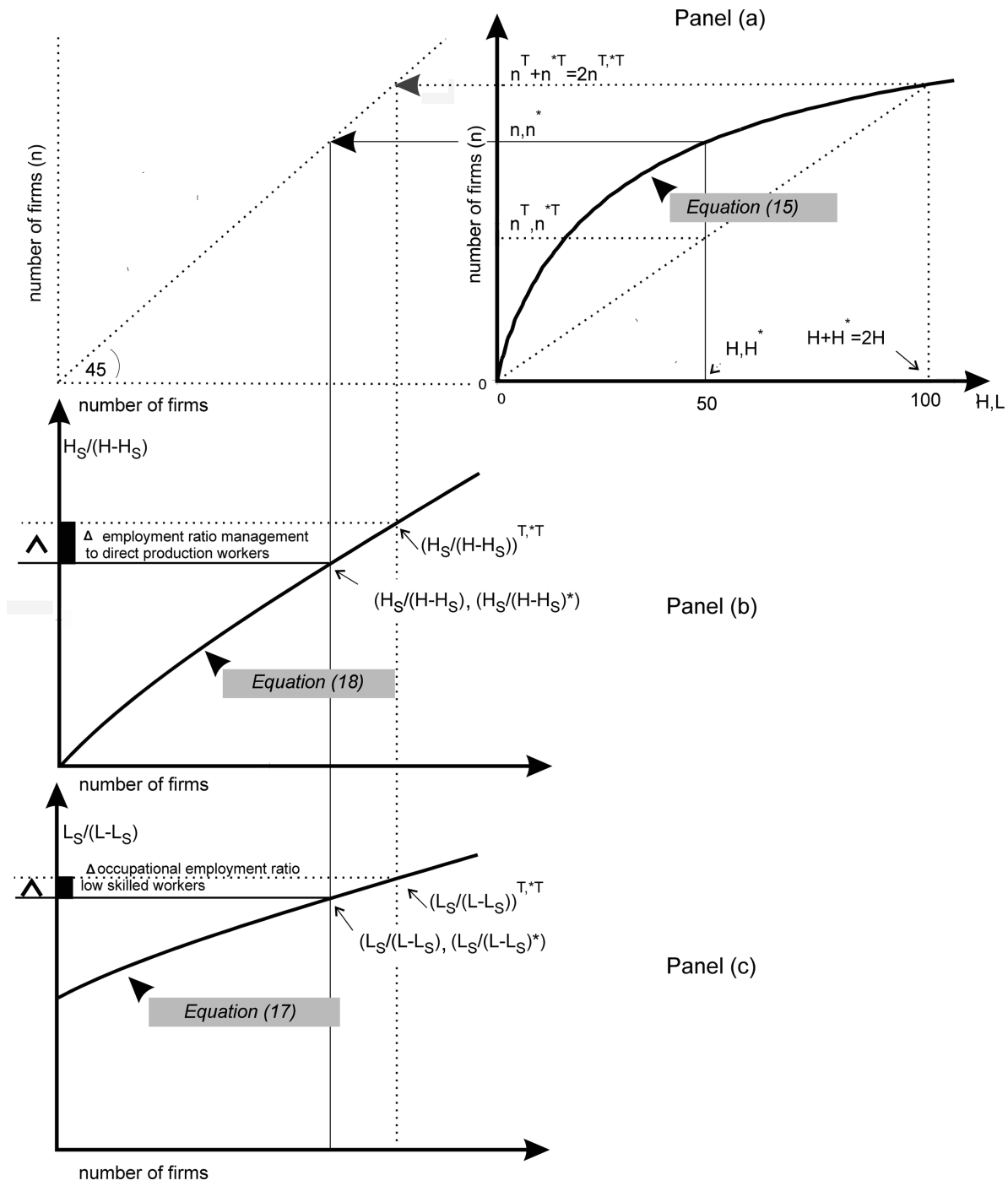

the world economy. Previously (that is before opening up) each economy (Home, Foreign) hosted firms $n, n^{*}$ with a total of 50 skilled and 50 unskilled workers ( $\kappa=\kappa^{*}=1$ ) employed in each country. In the benchmark case of two identical economies trading with each other, that is with factor supplies in the integrated economy twice as much, i.e. 100 plus 100 , the total number of firms in the world economy is $n^{T}+n^{* T}$, however with $n^{T}=n^{* T}<n+n^{*}$. Hence, the number of firms rises 
less than in proportion to factor supplies in the integrated area $(H, L)$.

The ray from the origin in Panel (a) displays the loci of all combinations of factor supplies and number of firms compatible with balanced trade according to (19), showing that after opening up all markets are cleared with $n^{T}, n^{* T}$ constituting a new equilibrium. However, as the number of firms declines, occupational employment ratios are being adjusted.

Panels (b) and (c) display equations (17) and (18), that is occupational employment ratios for high and low skilled labor as a function of the total number of firms in the trading area: before opening up, the total number of firms in each trading area, i.e. Home and Foreign, was $n$ and $n^{*}$ respectively, with occupational employment ratios of $H_{S} /\left(H-H_{S}\right)$ and $L_{S} /\left(L-L_{S}\right)$ for high and low skilled labor in Home $\left(\left(H_{S} /\left(H-H_{S}\right)\right)^{*}\right.$ and $\left(L_{S} /\left(L-L_{S}\right)\right)^{*}$ in Foreign); after opening up, and due to the productivity effect on business services, employment shifts towards services, and management in particular: $\left(H_{S} /\left(H-H_{S}\right)\right)^{* T}=\left(H_{S} /\left(H-H_{S}\right)\right)^{T}>\left(H_{S} /\left(H-H_{S}\right)\right)=\left(H_{S} /\right.$ $\left.\left(H-H_{S}\right)\right)^{*}$ and $\left(L_{S} /\left(L-L_{S}\right)\right)^{* T}=\left(L_{S} /\left(L-L_{S}\right)\right)^{T}>\left(L_{S} /\left(L-L_{S}\right)\right)=\left(L_{S} /\left(L-L_{S}\right)\right)^{*}$. In the end, more high skilled labor is being employed in business service occupations while low skilled labor is being laid off - and finds new employment in consumer services as the number of firms in Home and Foreign decreases. The y-intercept of each curve in Panels (b) and (c) displays labor allocation, if there was no fragmentation. Also, if cost effectiveness of fragmentation did not depend on the number of users but was exogenous, employment ratios would remain the same, even when opening up to trade.

\section{Net Sectoral Changes in Employment and Labor Flows: Discussion}

The model does not provide a full account of gross flows on the labor market. It purely focuses on the effects of IIT. In doing so, it abstracts from heterogeneity of firm-level demand as well as worker heterogeneity beyond skill groups or occupations. Presumably, both are related to specificities, learning of firms about their true competitiveness and the qualification of their workers, matching, unionization, unemployment insurance, various fixed costs of employment across occupations and skills etc. Only when adding these aspects can one explain simultaneous job creation and destruction at an even more disaggregated level, that is, within skill groups, or occupations for that matter. Notwithstanding the fact that the reallocation of labor is considered frictionless, the model provides additional 
information on and to changes in employment shares that result from trade-induced restructuring. Following the classification of Dunne/Roberts/Samuelson (1989), total labor reallocation in our model can be decomposed into three components:

(i) changes in the size and number of firms,

(ii) intraindustry job turnover and firm-level restructuring resulting in different jobs (or occupations) at the same employment level,

(iii) intersectoral employment shifts.

The third category equals net aggregate employment changes across sectors, while with respect to the former gross flows usually will differ from net employment flows due to occupational and skill heterogeneity.

Due to firm level restructuring actual labor turnover may be larger than indicated by net sectoral employment changes. The reasons for this difference are twofold:

1. If the expansionary effect of the productivity increase is smaller than the effect of upskilling (which depends on parameters $\alpha$ and $\eta$ ), firms may lay off workers (due to job destruction) while at the same time hiring new ones (for new positions, either because of restructuring or because of expansion).

2. A substantial amount of job turnover and labor reallocation occurs within firms. Since the extent of gross worker flows in excess of net changes in employment also depends on whether supply of business services is vertically integrated or market mediated, ${ }^{15}$ one may calculate upper and lower bounds of gross to net changes in employment.

At any rate, net changes of sectoral employment surely underestimate the magnitude of turnover in labor demand due to IIT.

The model highlights a second point: according to the previous literature (see

\footnotetext{
${ }^{15}$ For the US of the 1980 s there is some empirical evidence that displacement was more widespread among workers with low-skill production occupations. See Fallick (1996) for an overview. Greenaway/ Upward/Wright (2000, Fig. 8) also present U.K. data which suggests that flows of unskilled workers are larger. This is in line with the model presented in this paper to the extent that occupational reallocation of skilled workers from direct production to management takes place within industries or firms. However, Greenaway/Upward/Wright explain this in terms of higher sector specific human capital which keeps labor attached to industries. Bauer/Bender (2004) use a German employer-employee data set to examine whether job turnover (including intra-firm reallocation) is skill biased. Though their focus is on the impact of organizational change on job turnover, they find that the job destruction-job creation ratio is considerably higher for unskilled and medium skilled workers than it is for professionals, engineers and management, which may imply simultaneous entry and exit of workers into and out of firms. They also find evidence that investment in IT resulted in lower ratios for skilled workers, while the other two groups where more negatively affected (p. 18). Caroli/Van Reenen (2001) obtain similar results for the U.K. and France
} 
Sections 1 and 2), changes in employment shares have been difficult to reconcile with trade explanations. Yet, this model is able to account for a number of stylized facts of OECD labor markets, including the bimodal growth of high and low skilled services employment, and the recent concentration of demand for skill in management and business services occupations. Recent movements in wages have been in line with the sectoral reallocation of labor and with occupational change as outlined in this paper as well: As pointed out in the introduction, labor markets have been characterized not only by a shift in labor demand from the low to the high skilled and higher skill ratios within manufacturing but also by a bimodal increase in services employment (as in Panels (b) and (c)), and towards business services and management (necessary for managing a more fragmented production process) in particular. In particular in the US, average compensation in business services has increased much faster than in manufacturing or in personal services, retail, restaurants and hotels (OECD (2002b)). Yet, even an increase in average compensation in manufacturing (compared to personal services, retail, restaurants and hotels) were compatible with trade-induced restructuring. To the extent that the reallocation of labor between high skilled services and direct production takes place within manufacturing, average compensation in this sector increases rather than decreases, as due to the upskilling of the labor force less skilled workers leave manufacturing. Nevertheless, IIT-induced technical change involves considerable labor adjustment.

\section{Concluding Remarks}

In contributions to the theory of IIT based on the constant technology model, production of each of the varieties is invariant with respect to (trade-)integration and the size of the market. Consequently, the impact of IIT on labor markets can be expected to be low. There is considerable empirical evidence, however, that technology is not constant in the process of trade integration but changes endogenously, in particular with respect to the extent of fragmentation. At the same time, OECD-labor markets have witnessed substantial changes in employment (ratios) as well as job and worker flows in excess of net changes in employment, both at the level of the firm and at a sectoral level. These changes in employment have thus far been difficult to reconcile with a trade perspective.

The paper proposes a model of fragmentation in which the effectiveness of fragmentation in cost reduction is endogenous. Due to spillovers as well as learning 
and experimentation, cost savings in this framework depend on the number of users adopting a particular technology. Therefore, fragmentation changes endogenously with respect to trade exposure and so do job and worker flows. This optimizing behavior on the side of the firms with respect to technology has important implications for labor which thus far have not been captured by IIT with constant technology but are in line with recent labor market developments: employment shifts towards both high- and low-skilled services while the share of employment in direct production of manufactures in total employment declines, and the demand for skill in management and business services increases. Due to worker and job heterogeneity these changes in employment are accompanied by worker and job flows in excess of net sectoral employment changes. The model illuminates that some of this trade-induced labor reallocation takes place within firms and may result in firms laying off workers while at the same time hiring new ones. Also, if market size does matter for technology and if it implies a major reshuffling of the labor force, the usual presumption that IIT is not associated with major disruptions and structural change (unless it is combined with exogenous trade costs) turns out to be premature. The model lends itself to a number of extensions of which the introduction of imperfect labor markets and frictions in labor reallocation are the most straightforward.

\section{Acknowledgements}

This is a revised version of a paper presented at the Leverhulme Centre for Research on Globalisation and Economic Policy Conference "Trade and Labour Perspectives on Worker Turnover," University of Nottingham, the ETSG Meeting, Universidad Carlos III Madrid, the NOeG Meeting, Vienna University of Economics \& BA, and the World Congress of the IEA in Marrakech. Comments of conference participants as well as Carl Davidson, Carsten Eckel, Richard Freeman, Doug Nelson and Scott Schuh were very helpful and are gratefully acknowledged, as is financial support by the Deutsche Forschungsgemeinschaft (DFG).

Received 1 February 2005, Accepted 7 December 2005 


\section{References}

Andersen, T.M. and A. Sørensen, A. (2005), "Product Market Integration, Wages and Inequality". mimeo, Univ. of Aarhus, July.

Baldone, S.; F. Sdogati and L. Tajoli (2001), "Patterns and Determinants of International Fragmentation of Production: Evidence from Outward Processing Trade between the EU and Central Eastern European Countries", Review of World Economics 137, 80104.

Balassa, B. (1966), "Tariff Reductions and Trade in Manufacturing among the Industrial Countries", American Economic Review 56 (3), 466-73.

Bauer, T.K. and S. Bender (2004), "Technological Change, Organizational Change, and Job Turnover", Labour Economics 11 (3), 265-91.

Berman, E.; Bound, J. and S. Machin (1998), "Implications of Skill Biased Technological Change: International Evidence", Quarterly Journal of Economics 113, 1245-79.

Brülhart, M.; Murphy, A. and E. Strobl (2004), "Intraindustry Trade and Job Turnover", mimeo: University of Lausanne, University College of Dublin and University of Louvain.

Burda, M.C. and B. Dluhosch (2002), "Cost Competition, Fragmentation and Globalization", Review of International Economics 10 (3), 424-41.

Campa, J. and L.S. Goldberg (1997), "The Evolving External Orientation of Manufacturing: A Profile of Four Countries", FRBNY Economic Policy Review, July, 53-81.

Caroli, E. and J. Van Reenen (2001), "Skill-Biased Organizational Change? Evidence from a Panel of British and French Establishments", Quarterly Journal of Economics 116 (4), 1449-92.

Clark, D.P.; Herzog, H.W. and A.M. Schlottmann (1998), "Import Competition, Employment Risk, and the Job-Search Outcomes of Trade-Displaced Manufacturing Workers", Industrial Relations 37 (2), 182-206.

Davidson, C. and S.J. Matusz (2005), "Trade and Turnover: Theory and Evidence", Review of International Economics 13 (5), 861-80.

Davis, S.; Haltiwanger, J. and S. Schuh (1996), Job Creation and Destruction, Cambridge, MA: MIT Press.

Deardorff, A. (2000), "Fragmentation in Simple Trade Models", North American Journal of Economics and Finance 12 (2), 121-37.

Dixit, A. and J.E. Stiglitz (1977), "Monopolistic Competition and Optimum Product Diversity", American Economic Review 67, 297-308.

Dunne, T.; Roberts, M.J. and L. Samuelson (1989), "Plant Turnover and Gross Employment Flows in the U.S. Manufacturing Sector", Journal of Labor Economics 7 (1), 48-71.

Ekholm, K. and K. H. Midelfart Knarvik (2005), "Relative Wages and Trade-Induced Changes in Technology", Journal of the European Economic Association 49 (6), 
1637-63.

Ethier, W.F. (1982), "National and International Returns to Scale in the Modern Theory of International Trade", American Economic Review 72, 389-405.

Fallick, B.C. (1996), "A Review of the Recent Empirical Literature on Displaced Workers", Industrial and Labor Relations Review 50 (1), 5-16.

Falvey, R. and G. Reed (2000), "Trade Liberalization and Technology Choice", Review of International Economics 8, 409-19.

Feenstra, R.C. and G.H. Hanson (2003), "Global Production Sharing and Rising Inequality: A Survey of Trade and Wages", in: E.K. Choi and J. Harrigan (eds.), Handbook of International Trade, Oxford: Basil Blackwell.

Feenstra, R.C. and J.R. Markusen (1994), "Accounting for Growth with New Inputs", International Economic Review 35 (2), 429-47.

Finger, J.M. (1975), “Trade Overlap and Intra-Industry Trade”, Economic Inquiry XIII, 581-89.

Francois, J. (1990), "Producer Services, Scale, and the Division of Labor", Oxford Economic Papers 42, 715-29.

Francois, J. and D.R. Nelson (2000), "Victims of Progress: Economic Integration, Specialization and Wages for Unskilled Labor", CEPR Discussion Paper No. 2527.

Gaston, N. and D.R. Nelson (1997): "Trade and Wages in OECD Countries: Linking Theory and Evidence" mimeo, Tulane University.

Greenaway, D.; Upward, R. and P. Wright (2000), "Sectoral Transformation and LabourMarket Flows", Oxford Review of Economic Policy 16 (3), 57-75.

Greenaway, D.; Haynes, M. and C. Milner (2002), "Adjustment, Employment Characteristics and Intra-Industry Trade", Weltwirtschaftliches Archiv 138 (2), 25476.

Haltiwanger, J.C. and S. Schuh (1999), "Gross Job Flows Between Plants and Industries", New England Economic Review, March/April, 41-64.

Hijzen, A.; Görg, H. and R. C. Hine (2005), "International Outsourcing and the Skill Structure of Labour Demand in the UK", Economic Journal 115, 860-78.

Hummels, D.; Ishii, J. and K.-M. Yi (2001), "The Nature and Growth of Vertical Specialization in World Trade", Journal of International Economics 56, 75-96.

ILO Bureau of Statistics (2003), "LABORSTA: International Labour Office Database on Labour Statistics", http://laborsta.ilo.org, 3/2003.

Jones, R.W. and H. Kierzkowski (1990), "The Role of Services in Production and International Trade: A Theoretical Framework", in: R.W. Jones and A.O. Krueger (eds.), The Political Economy of International Trade, Oxford: Basil Blackwell, 3148.

Klein, M.W.; Schuh, S. and R.K. Triest (2003), "Job Creation, Job Destruction, and International Competition: A Literature Review", in Job Creation, Job Destruction and International Competition, W.E. Upjohn Institute.

Krugman, P.R. (1980), "Scale Economies, Product Differentiation, and the Pattern of Trade", American Economic Review 70, 950-59. 
Lovely, M. and D. Nelson (2000), "Marginal Intraindustry Trade as an Indicator of Labor Market Adjustment", Review of International Economics 8 (3), 436-47.

Lovely, M. and D. Nelson (2002), "Intra-Industry Trade as an Indicator of Labor Market Adjustment", Weltwirtschaftliches Archiv 138 (2), 179-206.

Magee, C.; Davidson, C. and S.J. Matusz (2005), Trade, Turnover, and Tithing, Journal of International Economics 66 (1), 157-76.

Neary, P. (2002a), "Foreign Competition and Trade Inequality", Review of International Economics 10, 680-93.

Neary, P. (2002b), "Competition, Trade and Wages", in: D. Greenaway, R. Upward and K. Wakelin (eds.), Trade, Investment, Migration and Labor Market Adjustment, Basingstoke: Palgrave Macmillan, 28-46.

OECD (2001), Labour Force Statistics 1980-2000, Paris: OECD.

OECD (2002a), Economic Outlook, Paris: OECD.

OECD (2002b), National Accounts 1989/2000, Vol. II, Detailed Tables, Paris: OECD.

OECD (2003), STI Scoreboard, Paris: OECD

Rangan, S. (2001), "Explaining Tranquility in the Midst of Turbulance: U.S. Multinationals' Intrafirm Trade 1966-97", BLS Working Paper \#336, January.

SAP (2003), "Preliminary First Quarter Results", Press Conference Presentation, April 2003, retrieved from http://www.sap.com/company/investor/presentations/, July 5, 2003.

Segelod, E. and G. Jordan (2004), "The Use and Importance of External Sources of Knowledge in the Software Development Process", R\&D Management 34 (3), 23952.

Thoenig, M. and T. Verdier (2003), "A Theory of Defensive Skill-Biased Innovation and Globalization", American Economic Review 93 (3), 709-28.

U.K. Office for National Statistics (2003), "National Statistics Online: Workforce Jobs by Industry", www.statistics.gov.uk/CCI/nscl.asp?ID=6610, 03/2003.

Venables, A.J. (1999), "Fragmentation and Multinational Production", European Economic Review 43 (4-6), 935-45.

Yi, K.-M. (2003), "Can Vertical Specialization Explain the Growth of World Trade?", Journal of Political Economy 111 (1), 52-102.

Zeile, W.J. (1997), "U.S. Intrafirm Trade in Goods", Survey of Current Business, February, Washington, D.C. 